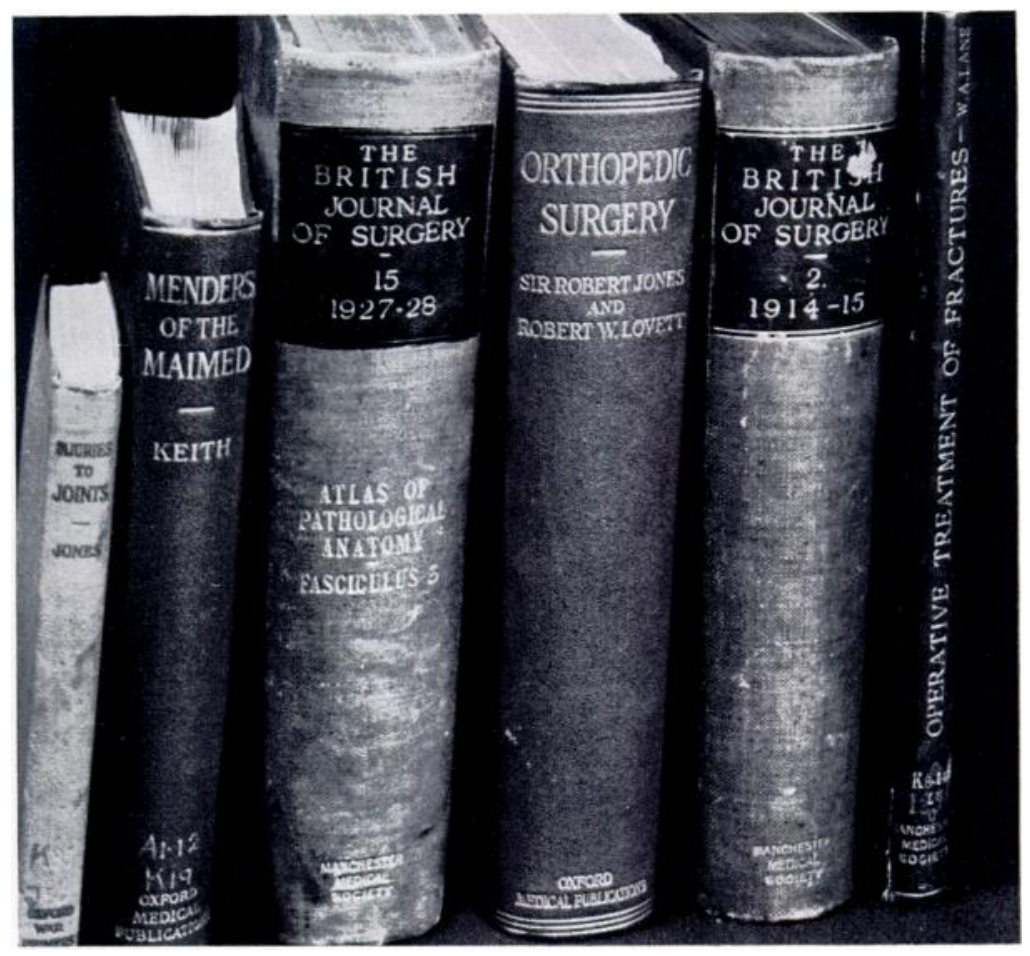

\title{
SOME CLASSICS OF BRITISH ORTHOPAEDIC LITERATURE
}

\section{Ll. Griffiths, Manchester, England}

Orthopaedic literature has changed less in Britain in the last fifty years than has the literature of other medical subjects. The day of the text-book by a single author is not yet passed; monographs and papers published in journals still possess the lively personal character that has distinguished British surgical writing in the past. In one sense this may reflect a lack of the coldly scientific outlook, but if our papers have not always been characterised by the accuracy that comes of statistical method and detailed experimental protocols they have also avoided the impersonal dullness which so often mars better science. British surgical literature has always had a humanistic touch: it still has.

In reviewing the products of this period one naturally thinks first of the writers andbefore all others-of Robert Jones who with his collaborators and pupils created so many of the classics of the period. However, before Jones there was Tubby, and before Tubby, Macewen. Macewen-Sir William Macewen, whose name is one of the greatest in the whole history of surgery, was so much a figure of the nineteenth century that one recalls with a little surprise that his last publication on bone growth was dated 1923, and with even more that his classic work on osteogenesis appeared in 1912. The Growth of Bone is a model of surgical writing. It is short, very clear and one of the most interesting books in any surgeon's library. It masses its detailed evidence logically and carefully, and the fact that so little of the experimental work it reports has been questioned after many confirmatory experiments is a further sign of its unique quality. Most of the work was done, and much of it published, before the turn of the century, but Macewen had to wait until 1908 to see the radiographic evidence (now reproduced again on the next page) which gave him final proof of the success of his classic experiment in homogenous bone grafting. One can only wonder that this remarkable book and the work it recounted have been of so little avail in preventing the misleading 
" chemical" theories of bone formation which led orthopaedic physiology far astray less than twentr vears later.

Tubby - In the first year of this century the standard British text-book of its subject was

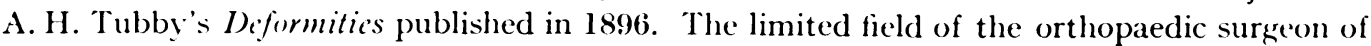
those days is shown by a remark in the preface that it did not include " tubercular osteitis and arthritis of the hip and knee," which was still the province of the general surgeon. $13 y$ 191:2 those limitations had gone and Tubby's second edition had to be rewritten almost completely. The title then became Deformitie's, including Diseases of the Bones and Joints, a Text-book of Orthopaedic Surgery. The book was enlarged and filled two volumes. "Rontgen-ray illustrations" were made from negatives belonging to Thurstan Holland and Alban Köhler, and the first really modern text-book of orthopaedics was thus produced in Britain. It is still of great value, though perhaps more for its account of deformities than for the additions which completed it. Read after the lapse of fort $y$ vears, the first edition is the better book.

Robert Jones-In 1903 Tubby co-operated with Robert Jones in a small book of three hundred pages on the Surgery of Paraly'sis. Jones already had several papers to his credit before the turn of the century and this book is an interesting part of his literary output before the first world war. It is no doubt much less important than his famous address to the Surgical Section of the Royal Society of Medicine in 1910 on "Fractures in the Neighbourhood of Joints," in which he laid down the principles of mobilisation of elbow injuries and his condemnation of passive movement; nevertheless it is an interesting landmark in pre-war orthopaedic literature. Another paper, published in the first issue of the British Journal of Surgery in 1913, was written with Alwyn Smith on ruptured crucial ligaments and fractures of the tibial spine; but in literature as in other matters it took the first world war to bring the full flowering of Robert Jones.

His first war book, Injuries to Joints, was written (as we were told by Mc.Murray) in two weeks. It had been requested by the Army Medical Department and was published in 1915 as an Oxford War Primer. A pocketsized book with a few vivid illustrations, it reached three editions and was many times reprinted. The help of McCrae Aitken was acknowledged in the first two editions, and of Harry Platt in the third edition published

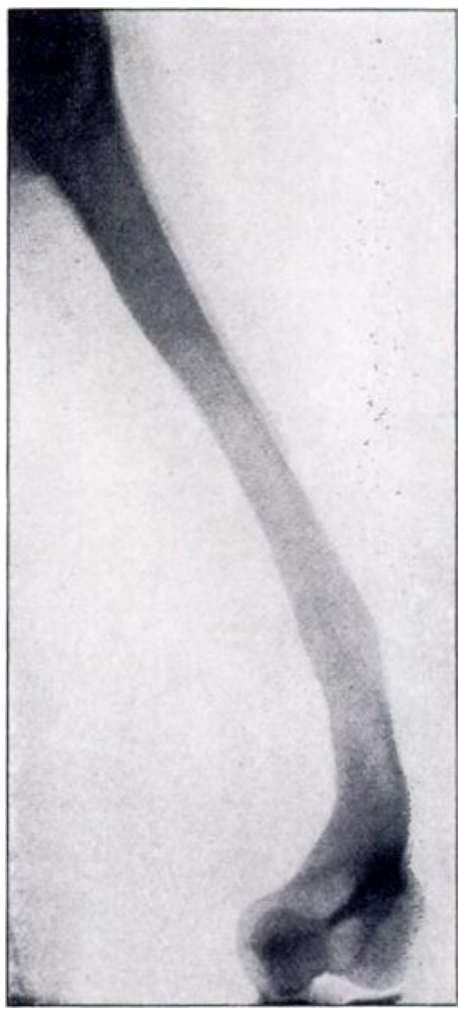

Figure 60 from Macewen's Growth of Bone (published in 1912 by James Maclehose \& Sons). The regenerated humerus thirty vears after replacement of almost the whole diaphysis by pieces of tibia obtained during wedge osteotomies for knock-knee. One of Macewen' classical experiments which discredited the periosteum as the sole source of new bone. in March 19:30.

Notes on . Military Orthopaedics appeared in 1917. This was the parent of a handsome two-volume post-war book Orthopaedic Surgery of Injuries by various authors under the editorship of Robert Jones. The preface included his much misquoted definition: " Orthopaedic surgery is based on, and consists of, the recognition and practice of definite principles of treatment, whether operative, manipulative or educational, which lead to the restoration of function in nerves and muscles and in deformed or disabled limbs." (Page vii.) Jones himself wrote the chapters on malunion of the femur, ankylosis and stiff joints, and flail joints. The second volume included contributions by Stiles and Bristow on peripheral nerve injuries, and by Wood Jones on trick movements. It is unique among orthopaedic books in that one

VOL. $32 \mathrm{~B}$, NO. 4, NUENBER 1950 


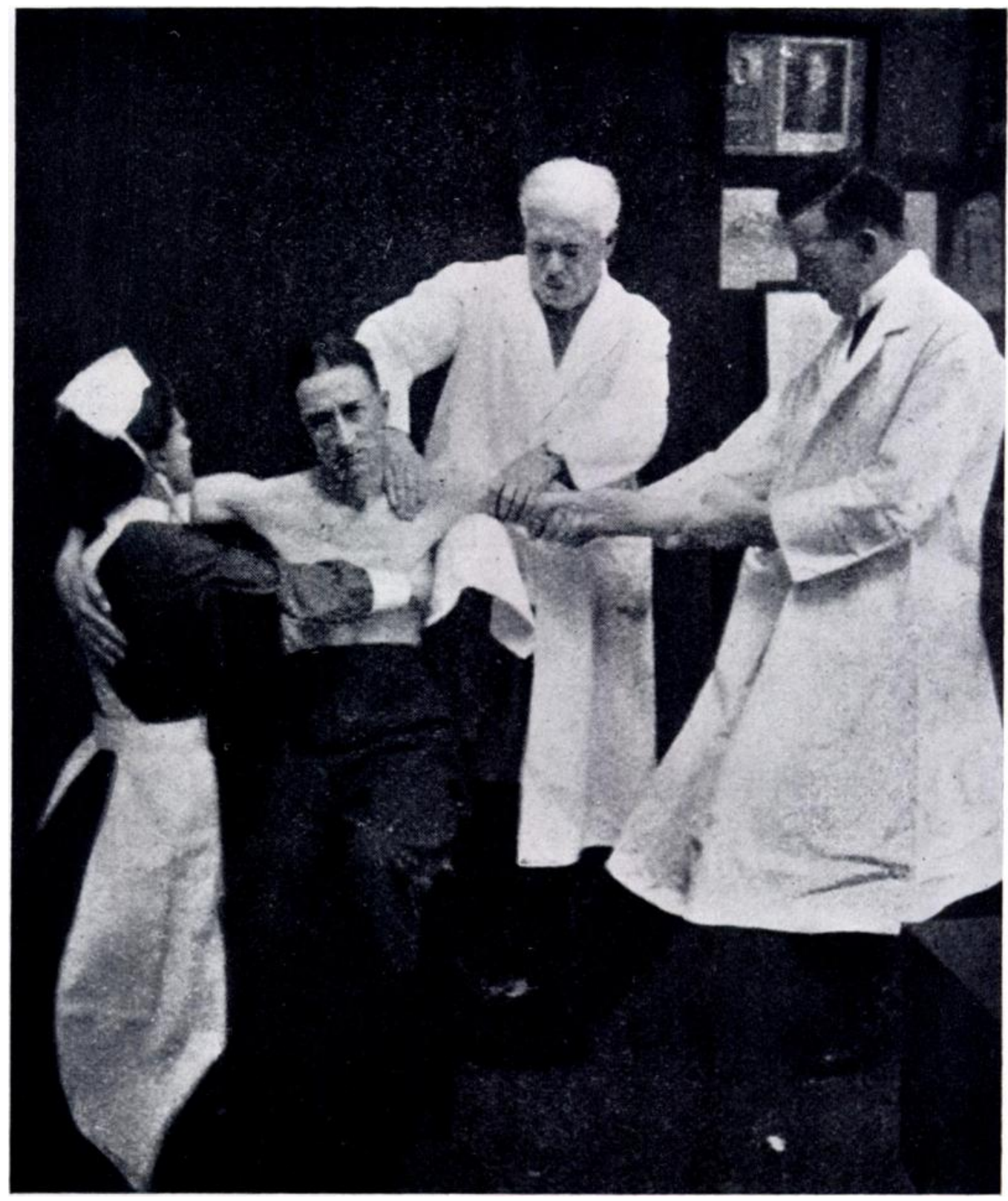

Fig. 5. Reducing Dislocated Shoulder.

The photograph above is reproduced from page 66 of Injuries to Joints, which was published in 1915 as an Oxford War Primer. Robert Jones, reducing a dislocation over his knee, is assisted by T. I'. Mlc.Murray. 

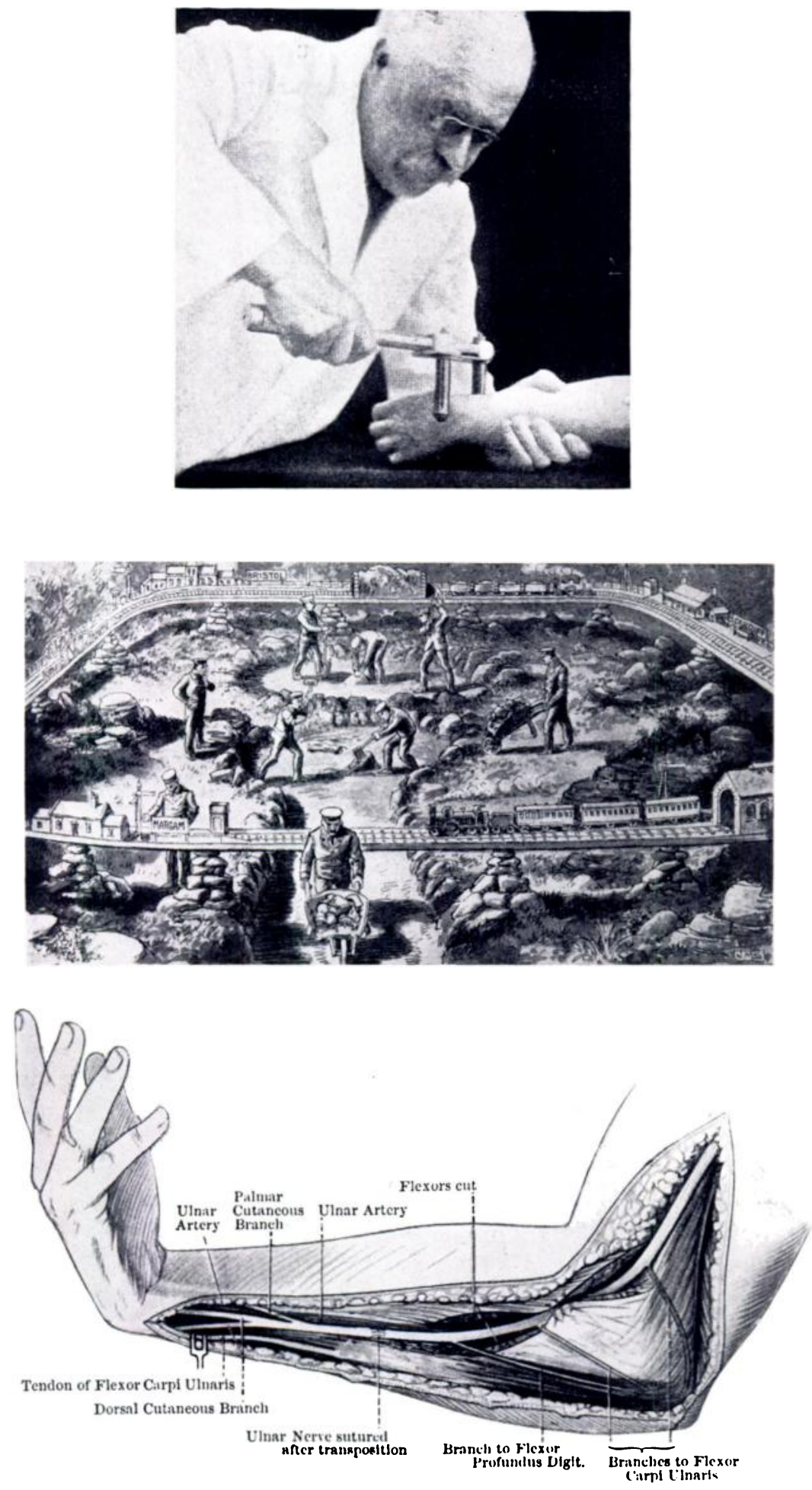

Three illustrations from Orthopaedic Surgery of Injuries (Oxford Nedical Publications, 1921). At the top Robert Jones is using a Thomas's wrench to refracture a malunited Colles fracture. Below this is a sketch, "Training ground for artificial arms," from the chapter contributed by Lynn-Thomas. The drawing of the forearm, showing resection of a lesion of the ulnar nerve and end-to-end suture after anterior transposition of the nerve at the elbow, is from stiles's chapter on "Injuries of the Peripheral spinal Nerves."

VOL. 32 B, No. 4, NOVEMBER 1950 
chapter was written by a king-the exiled King Manuel of Portugal who was Jones's friend and worked with great enthusiasm at Shepherd's Bush; he wrote on the "Scheme and Organisation of Curative Workshops."

"Jones and Lovett "-For many years Jones and Lovett's Orthopaedic Surgery, first appearing in 1923, was the standard text-book of the English-speaking orthopaedic world. It was, of course, chiefly an American work, printed in America, and originally more Lovett than Jones. Purporting to be "a plain and practical account of those pathological conditions which we believe may properly be classified under the unsatisfactory name of orthopaedic surgery," it owed ancestry to the American work, Bradford and Lovett's Treatise on Orthopaedic Surgery (1890). The story of the book is told so well in Watson's Life of Robert Jone's that nothing need

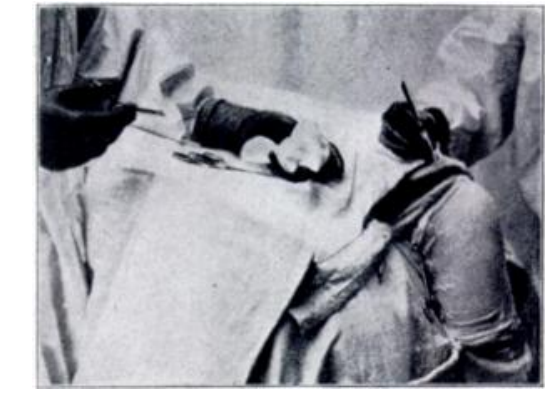

Fic. 30-Field of operation on cartilage

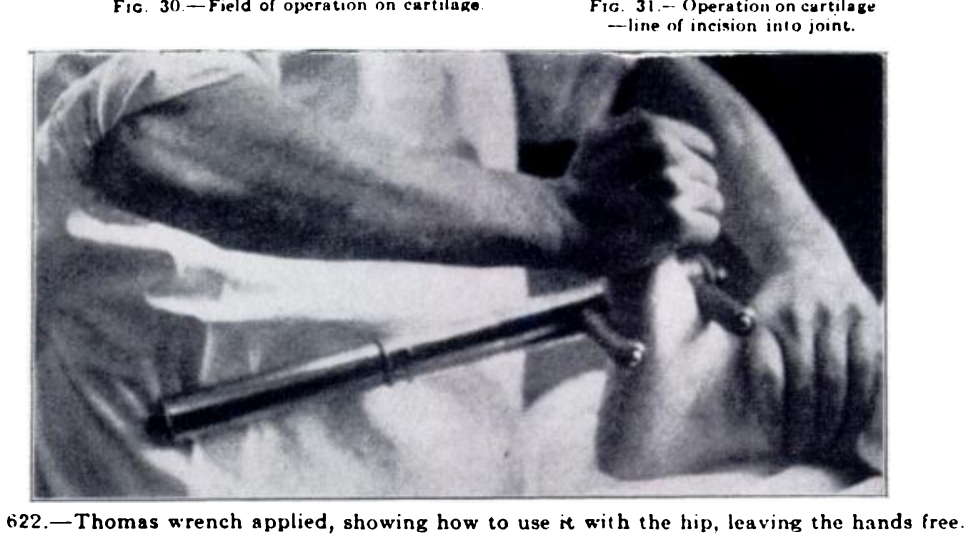

Illustrations reprinted from pages 33 and $\mathbf{5 9 1}$ of Jones and Lovett (Orthopaedic Surgery, London 1923, published by Henry Frowde, Hodder and Stoughton).

be added-except perhaps to record the reply made by Robert Jones when the great novelist Joseph Conrad said that two thousand words a day was a desirable output. Jones, making far slower progress, remarked: "But I have to be accurate." The book is beautifully made and compares favourably with the great text-books of any branch of medicine. The illustrations can still be reproduced and show the original Jones manipulations quite unambiguously.

Lovett died in Robert Jones's home in Liverpool the year after the book was published. The second edition in $\mathbf{1 9 2 7}$ was entrusted to Allison and Ober in the Lnited States, while a very thorough revision was made in England by Robert Jones with the assistance of Harry Platt. A third edition, more than once planned, never appeared.

The Robert Jones Birthday Volume-Robert Jones's seventieth birthday was celebrated with one of the few "Festschriften " ever presented in British medicine. This book, The Robert Jones Birthday Volume, consisted of twenty-three essays on various orthopaedic subjects, seventeen written by old colleagues, assistants and pupils, two by his American friends 
SOME CLASSICS OF BRITISH ORTHOPAEDIC LITERATURE

681

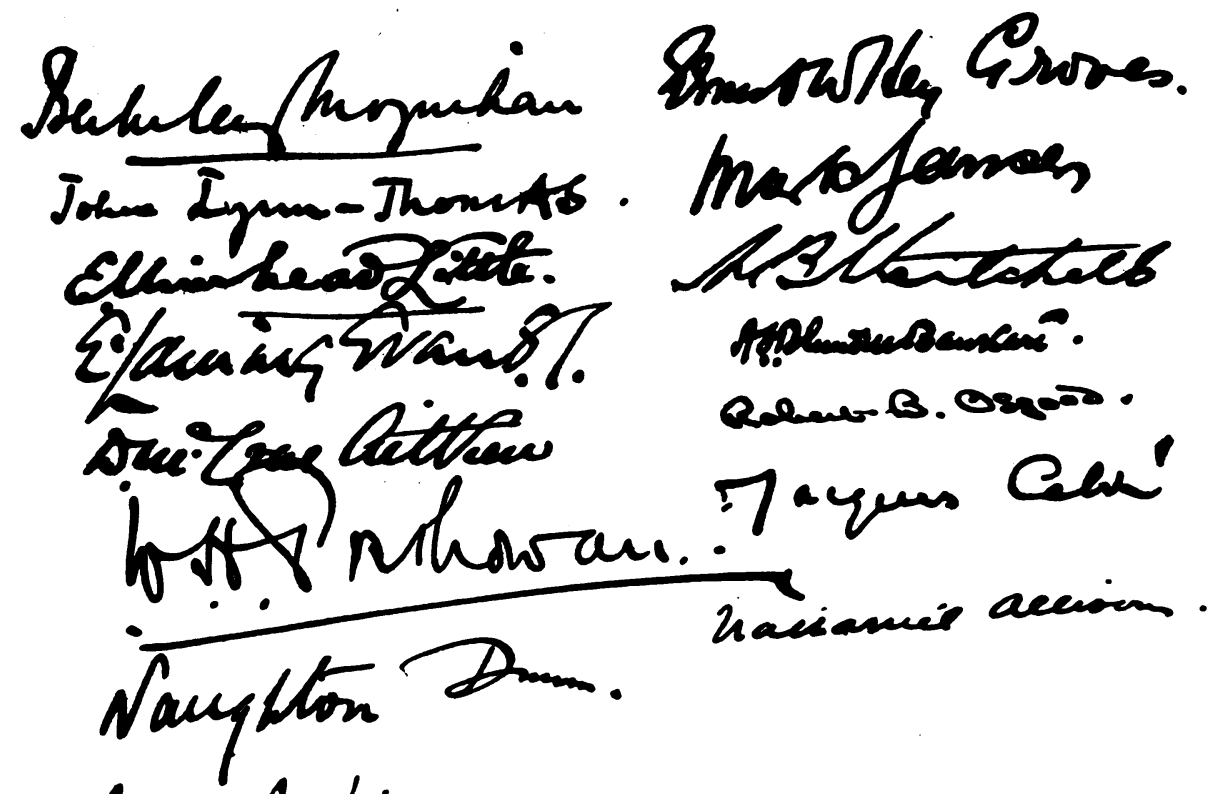

Sharking Printing:

Cinurstan Holland.

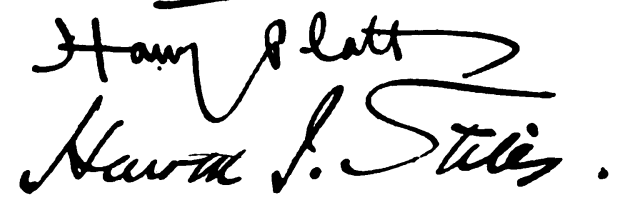

hlaghauler

bothicibate.

Imemumay

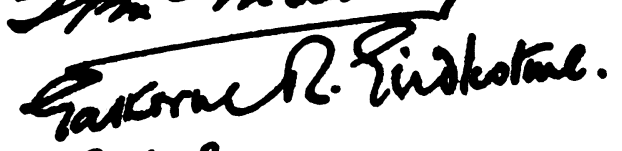

ク.C. C Than:

The signatures of the contributors in the original Birthday Volume-photograph taken and published here by permission of the Orthopaedic Library of the Liverpool Medical Institution.

VOL. $32 \mathrm{~B}$, No. 4, NOVEMBER 1950 
part is situated much more distally than in the normal one of Fig. 9. This seems to indicate that the growth disc in the upper end of the femur adds more to the longitudinal growth of the femur than corresponds with the longitudinal growth of the femoral neck. In Fig. 10 a small femur has been drawn on a large one. and the place has been marked to which its parts have wandered after years of growth. It might be imagined that the femoral neck increases just enough in length to allow the trochanters to reach their ultimate position-as is indicated by the dotted (narrow) femoral neck - whilst at the same time the trochanters, enlarging, departed from the axis of the neck, thus following the shaded area, indicated in Fig. 10. In that case, however, it would be unintelligible that distally from the normal site of the lesser trochanter in Fig. 8 bony masses should occur which present themselves as rests of a displaced lesser trochanter. If, therefore, these masses are indeed such

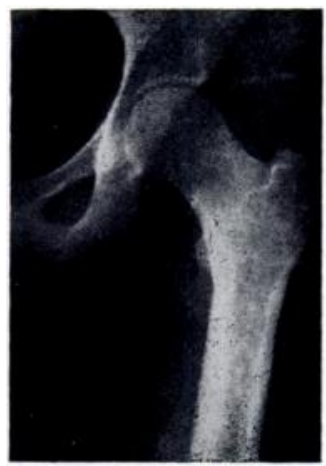

Fig. 9 (normal parts for comparison)

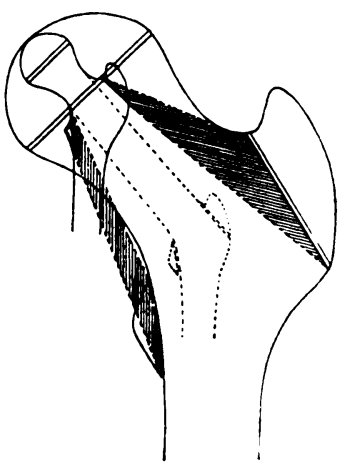

Fic. 10.

rests, the conclusion is justified that the growth dise in the upper end of the femur adds more to the length of the femur than corresponds with the longitudinal increase of the neck. From this it would follow that during growth an intricate process of displacement of the trochanters upwards and inwards is necessary with regard to the mass of the femoral neck which through growth pushes downwards and outwards; while. moreover, the curve in the area of transition between femoral neck and diaphysis and the curves in the cancelli inside the neck have constantly to shift from the upper portion of the diaphysis upward and inward. At all events the enlarged trochanters. the lessened obturator foramina and the widened socket floor in our patient display. hitherto unknown phenomena in Ollier's dysschondroplasia whose nature seems to be identical with those discussed above, since they present themselves as a dissociation of one of the growth processes from the others, viz. a dissociation of resorption.

The above considerations on the growth of the femoral neck may be useful in furnishing an insight into the origin of the exostoses on the ribs of our patient W. I.

A page from "Dissociation of Bone Growth" by Murk Jansen, in The Robert Jones Birthday Volume. 
with the characteristic trangular fragment showing well in the radiograms. In the first case there was no coxa vara. On general $\mathbf{X}$-ray examination alisthese cases, however, showed a large number of other abnormalities of the skeleton, to which attention had been drawn by Mr. Barrington-Ward when he exhibited his case before the British Orthopedic Association when they visited the Hospital for Sick Children, Great Ormond Strect, in 1924. In addition to the deficient ossification of the skull (parictals) and of the elavicles, these included entire absence of ossification of both pubic bones, epiphyes at either end of several metacarpals and phalanges, delayed fusion of the mandible and of the neural arches, and no sign of ossification

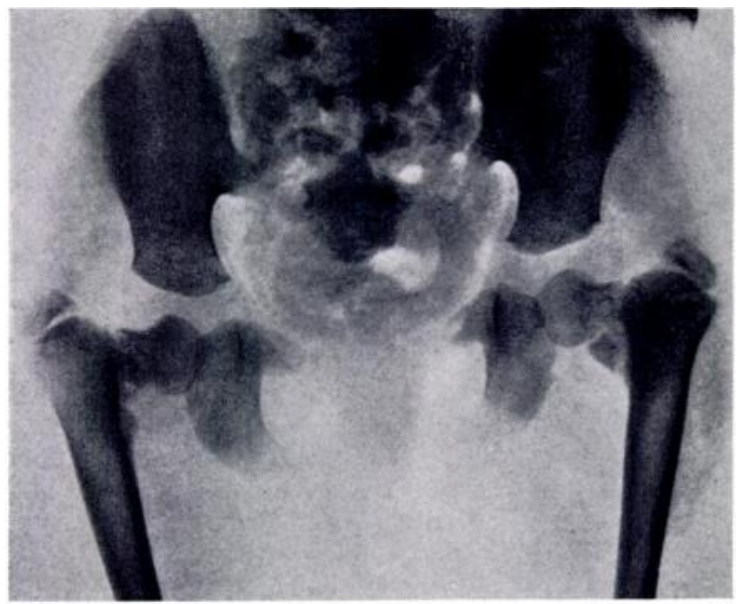

Fis. 15.- Bilateräl infantile coxa vara in case of cranio-cleido-dysostosis. Girl aged ti years. Note the typical triangular fragment, and other features of infantile coxa vara on both sides, and also the absence of ossification in the pulxes.

of the carpal bones. There can be no doubt about this combination of abnormalities being the result of developmental errors, and the occurrence of this type of coxa vara with this condition must be regarded as the strongest possible evidence in favour of the latter also being the result of an error of development. The cause of the dysostotic affection is unknown, but various suggestions have been made. In my opinion the only theory which could account for all the abnormalities seen is that the condition is a reversion to a lower type. The clavicles are rudimentary in the carnivora and absent in the cetaceans, but I have been unable to find out whether the ossification in these agrees in other ways with that seen in the dysostotic human beings. A somewhat limited examination of the femora of these two classes in the muscum of the Royal College of Surgeons has failed to disclose any specimen with marked coxa vara. The angle of inclination in the femora seen was undoubtedly less than.

From "Infantile or Cervical Coxa Vara," contributed to the Birthday Volume by H. A. T. Fairbank. 

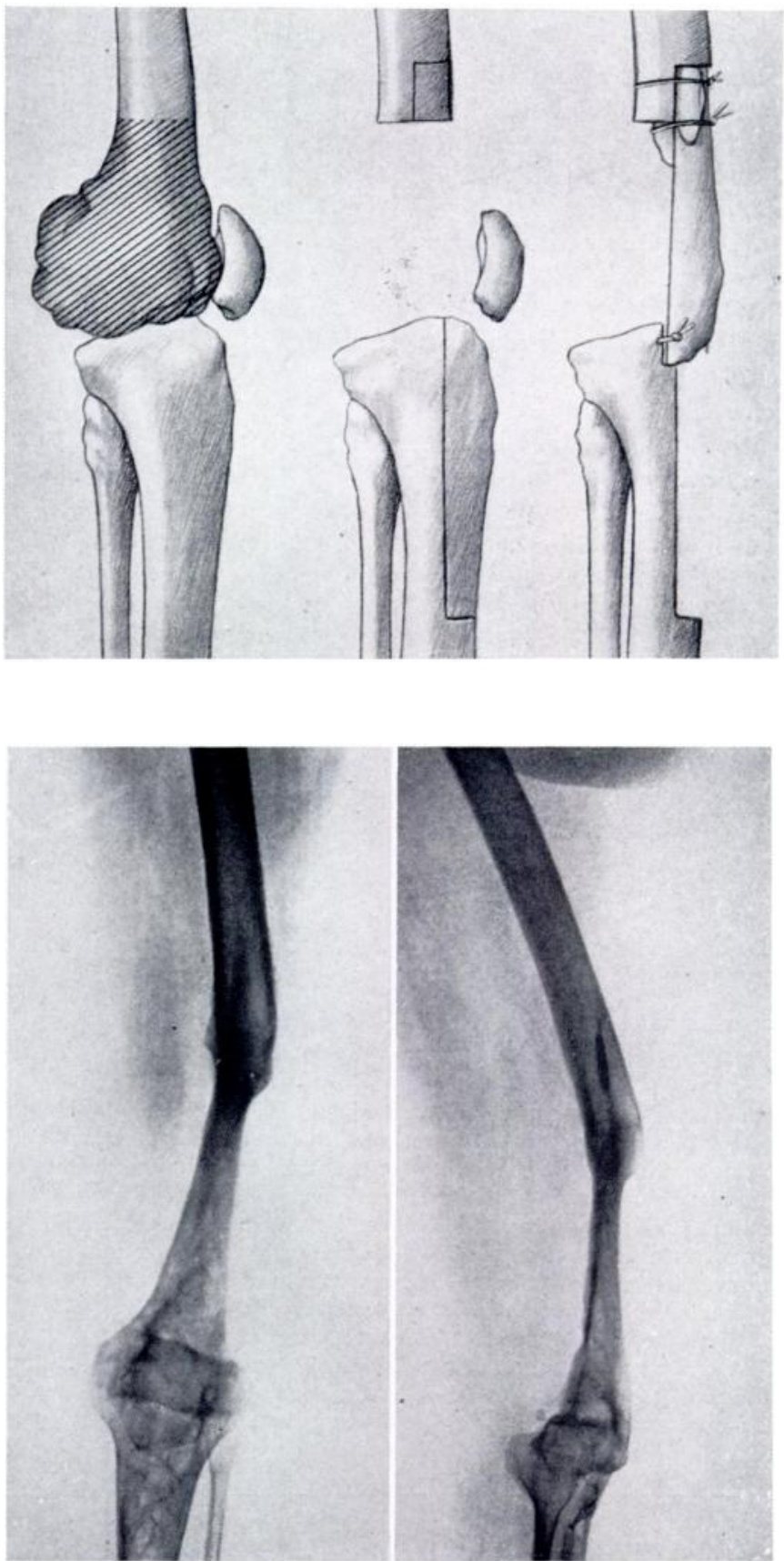

Putti's illustrations of replacement of the lower end of the femur with a graft from the upper end of the tibia after excision of an osteoclastoma. (From the Birthday Volume.) 


\title{
OSTÉO-CHONDRITE VERTÉBRALE INFANTILE
}

Par Jacques Calvé, M.D.

Surgeon-in-chief, Hopital franco-americain, Berck-Plage, France

\begin{abstract}
DEPUIs 1924, où j'ai décrit pour la première fois une affection particulière de la colonne vertébrale chez l'enfant, simulant le mal de Pott, individualiste par un syndróme radio-clinique caractéristique, 17 observations nouvelles, dont une inédite, ont été rapportées sur le mêne sujet sous la dénomination "ostíc-chondrice vertébrale", terme que je proposais moi-mème à cause des similitudes que présente cette nouvelle affection avec l'ostéo-chondrite de la hanche et la maladie dite de Koehler. Ceci porte donc à 9 , tout au moins à ma connaissance, le nombre des observations d'ostéo-chondrite vertébrale de l'enfant :
onnaissance,

1 cas personnel, 1 cas de Brackett, de Boston, \}cas déjà publiés dans mon premier travail.

1 cas de Brackett, de Boston, 2 cas de Harrenstein, d'Amsterdam,"

2 cas de Buchman, de Brooklyn,"

1 cas de Kleinberg, cité par Buchman.

I cas de Gallie, cité par Buchman,

1 cas inedit de Platt, de Manchester.
\end{abstract}

Syadrôme radio-clinique de l'oetco-chondrito vertóbrale infantile

Toutes ces observations sont sensiblement calquées l'une sur l'autre. Il s'agit, en général, d'un enfant de 5 à 10 ans qui, au point de vue clinique, presente les signes caractiristiques d'un mal de Pott :

douleur à la pression d'une apophyse tpineuse :

contracture du rachis

apparition progressive dune gibbasite mediane et angulaire ;

Dans 3 cas seulement, la déformation, au lieu d'étre médiane, est latérale : l'enfant est contracturé en position scoliotique. ' (Observation de Buchman, observation de Kleinberg cité par Buchman et observation inédite de Platt.)

A la radiographie. on trouve, en général, que la lésion frappe un seul corps

- Calvi. Jacques. "A Localised Affection of the Spine suggesting Osteochondritis of the Vertehral Bewly with the (linical Aspects of Pott's Disease," Jour. Bone and Joint Surg. vii. 41, ,lan, 1925.

Sirnternitulruek aus Zeitschnft far orchopddische Chirurge, xlvii. Bd.

The .Jumrual of Bone and Jnint Surg., Jan. 1928.

Title page of Calvé's essay contributed to the Birthday Volume.

This injury is almost pecullar to athletes,

epileptics, both of whom are liable to sustain dislocation by direct violence in the manner already described. Most of the former class are powerful, healthy, athletic young men to whom the frequently recurring dislocation from trivial causes is a great and serious disability. In epileptics the dislocation sometines recurs with every fit. The dislocation is nearly always antcrior, rarely posterior.

Some cases have been described in which fractures, either of the anterior margin of the glenoid cavity or of the greater tuberosity of the humerus, have been associated with recurrent dislocation. Such fractures are caused by the direct force which produces the initial dislocation, but they must be regarded as incidental, and not essential, to the recurrent dislocation. The essential feature is the detachment of the capsule from the fibro-cartilaginous glenoid ligament.

The treatment of recurrent dislocation of the shoulder is operative and consists in reattaching the fibrous capsule to the glenoid ligament, or fixing it to the bone at the anterior margin of the glenoid cavity. The operation is as follows :

Extract from A. S. Blundell Bankart's essay on recurrent dislocation of the shoulder joint. (From the Birthday Volume.) 

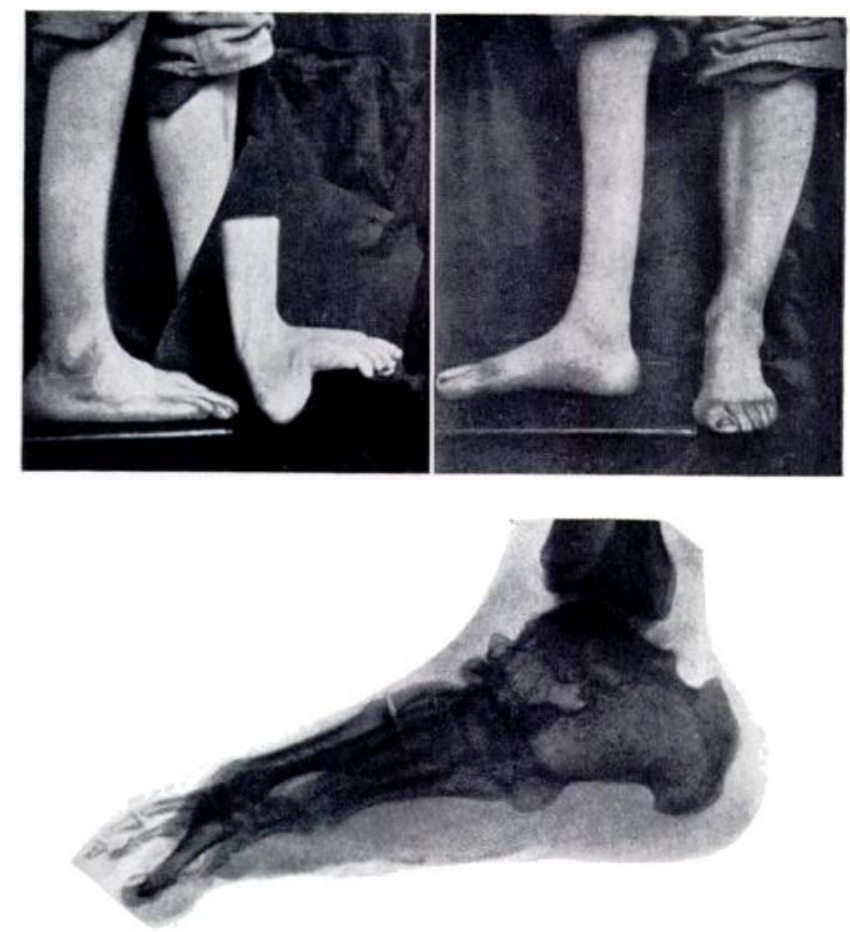

Fias. 11, 12, and 13.- Case F. M. Cast shows position of foot prior to operation at age of 12 . X-ray and photographs eight and a half years later show no recurrence of deformity and the presence of sound mid-tarsal and subast ragaloid arthrodesis.

Illustrations from Naughton Dunn's essay on the treatment of foot deformities. (From the Birthday Volume.)

Allison and Osgood, one by Clarence Starr of Canada, and others by Putti, Jansen and Calvé from Italy, Holland and France. The preface was by Moynihan and the last chapter was an appreciation of Robert Jones by Lynn-Thomas. The book came as a complete surprise to Jones, who was delighted by it. It was published in 1928 by Humphrey Milford and, although it is rare and was never reprinted, its influence on British orthopaedics has been felt ever since. Oddly enough it is to the European contributions that reference is made most often, for Jansen's essay on "Dissociation of Bone Growth," and Calvé's contribution on " Ostéochondrite Vertébrale Infantile" are still standard essays. The book includes Naughton Iunn's best account of his stabilising operation on the foot, as well as outstanding contributions by Fairbank on infantile coxa vara and by Platt on nerve lesions in elbow injuries.

Arbuthnot Lane-Lane had written on the operative reduction of tibial fractures in 1894. In 1905 he summarised thirteen years' work in The Operative Treatment of Fractures-a book of one hundred and forty-four quarto pages in beautiful large-size type, illustrated with surprisingly good radiographs and excellent pictures of the Lane instruments. In 1914 there was a second edition of this volume which laid down principles rather than details. In many ways it is a sad book: if its principles had been appreciated and followed, and indeed if the pages had even been read carefully, the disasters that followed its publication might not have happened. Lane made everything look so easy that his methods were thrown into undeserved disrepute when bad plating produced bad results. 

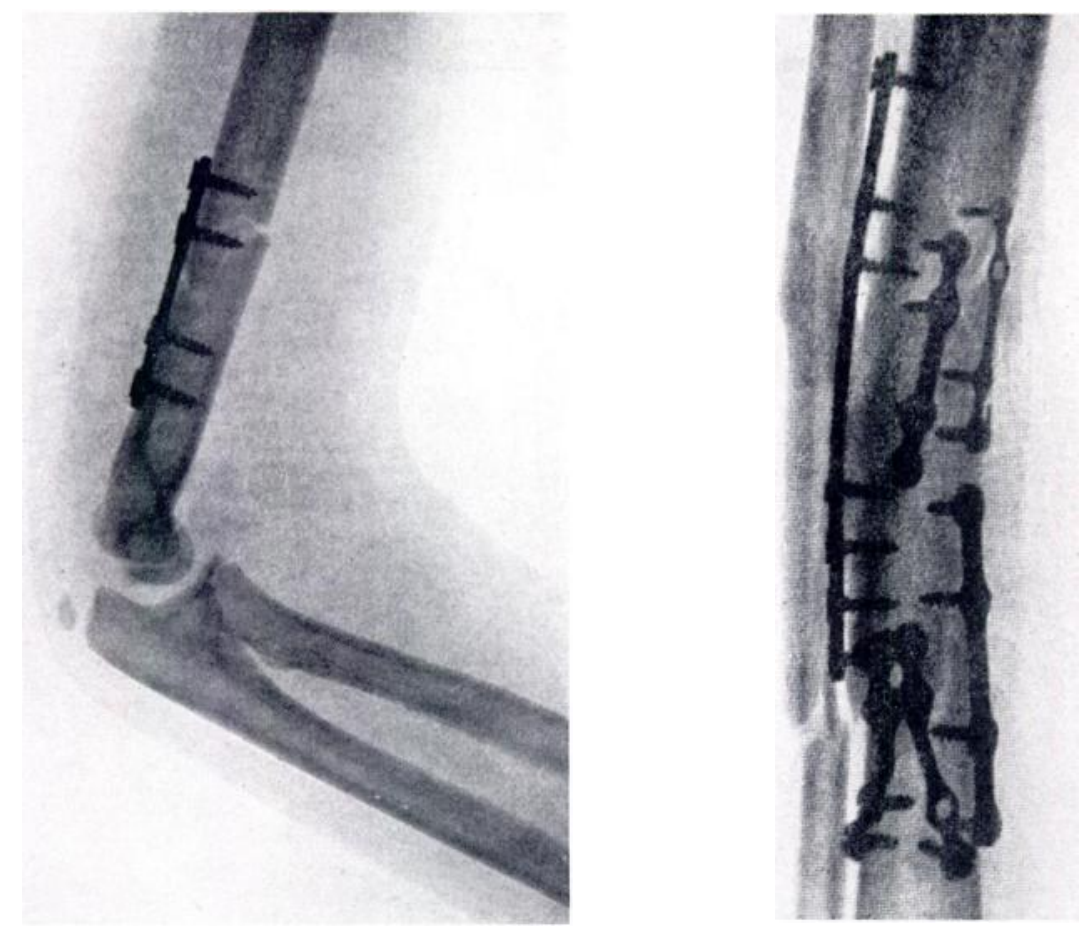

(I.eft) Typical radiograph in Lane's The Operative Treatment of Fractures (reproduced here from the second edition, published in 1914 by The Medical Publishing Co. Ltd.), showing a plated fracture of the humerus; note the quality of the radiograph. The right-hand illustration shows the use of an unusually large number of plates for " reposition of the parts " after a comminuted fracture of the tibia.

"Menders of the Maimed"-A major contribution to orthopaedic thought was made in 1919 when the eminent anatomist Arthur Keith published the lectures he had given at the Royal College of Surgeons upon the principles of orthopaedic treatment as laid down by those whom he styled "menders of the maimed." The lectures had already been printed individually but the book was a coherent revision with the subtitle "The Anatomical and Physiological Principles Underlying the Treatment of Injuries to Muscles, Nerves, Bones and Joints." Keith records in his autobiography an early belief that the book would sell well, and his later realisation that on the whole it did not. He attributes some of that failure to the covers, which were of the sort "usually given to heary monographs on science, and Menders certainly does not belong to that class of literature." Still, there was a second edition in 1925. This book really is a classic; it is beautifully written and should be part of the compulsory reading of every young orthopaedic surgeon. Knowledge of its contents would prevent a great deal of useless self-styled research and would steer ideas correctly on the lines of the proper natural history of our art.

Hey Groves-A small book of two hundred and eighty-six pages, published in 1916, should be in the library of every fracture clinic. On Modern Methods of Treating Fractures by E. W. Hey Groves has lost little of its original modernity; indeed, if the author had enjoyed the advantages of modern metals he would-as Watson-Jones has reminded us-have gained credit for many techniques that were his conception but impossible in human surgery until 


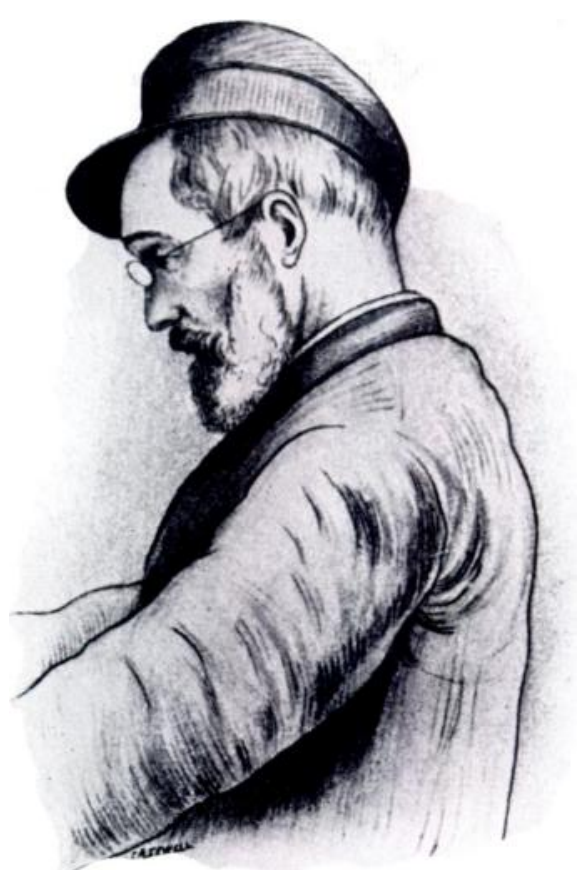

HUGH OWEN ThOMAS,

From a sketch made about 1884 when he was in his fiftieth year. He died on 6th January 1891 in his fifty-seventh year.

\section{GHAPTER III}

\section{THE PRINCIPLES AND PRACTICE OF HUGH OWEN THOMAS}

Hugh Owen Thomas was born when his mother was on a visit to her parents at Bodedern, Anglesey, 23rd August 1834. Her husband, Evan Thomas, was also a native of Anglesey, where his forefathers for many generations had practised as bone-setters. At the time of Hugh s birth his father had established his home in Liverpool, where his fame as a bone-setter had already spread beyond the confines of the city. Hugh was a delicate child, and, on account of his health, was brought up in the country, altending school first in Anglesey, then in St. Asaph, and afterwards, when he lived at home, Dr. Poggi's school, in New Brighton. His professional career may be divided into the three following stages :

35

Page 35 of Menders of the Maimed, Arthur Keith. Published in 1919 by the Oxford University Press, Henry Frowde, Hodder and Stoughton. 
rustless steel was introduced. This book was an expansion of the Hunterian lectures he gave in 1914 on experimental fractures and their union. The experiments he described included plating, the insertion of steel intramedullary nails and beef-bone pegs, the fixation of fractures by nails and clamps, and most of the "advances" in operative treatment that have been made since.

The British Journal of Surgery-Any mention of Her Groves leads naturally to the British Journal of Surgery which he served so long and so well. This wonderful journal, the best of its kind in the world, published nearly all important British contributions to orthopaedic literature from 1913 to 1947 and until the British volumes of the Journal of Bone and Joint

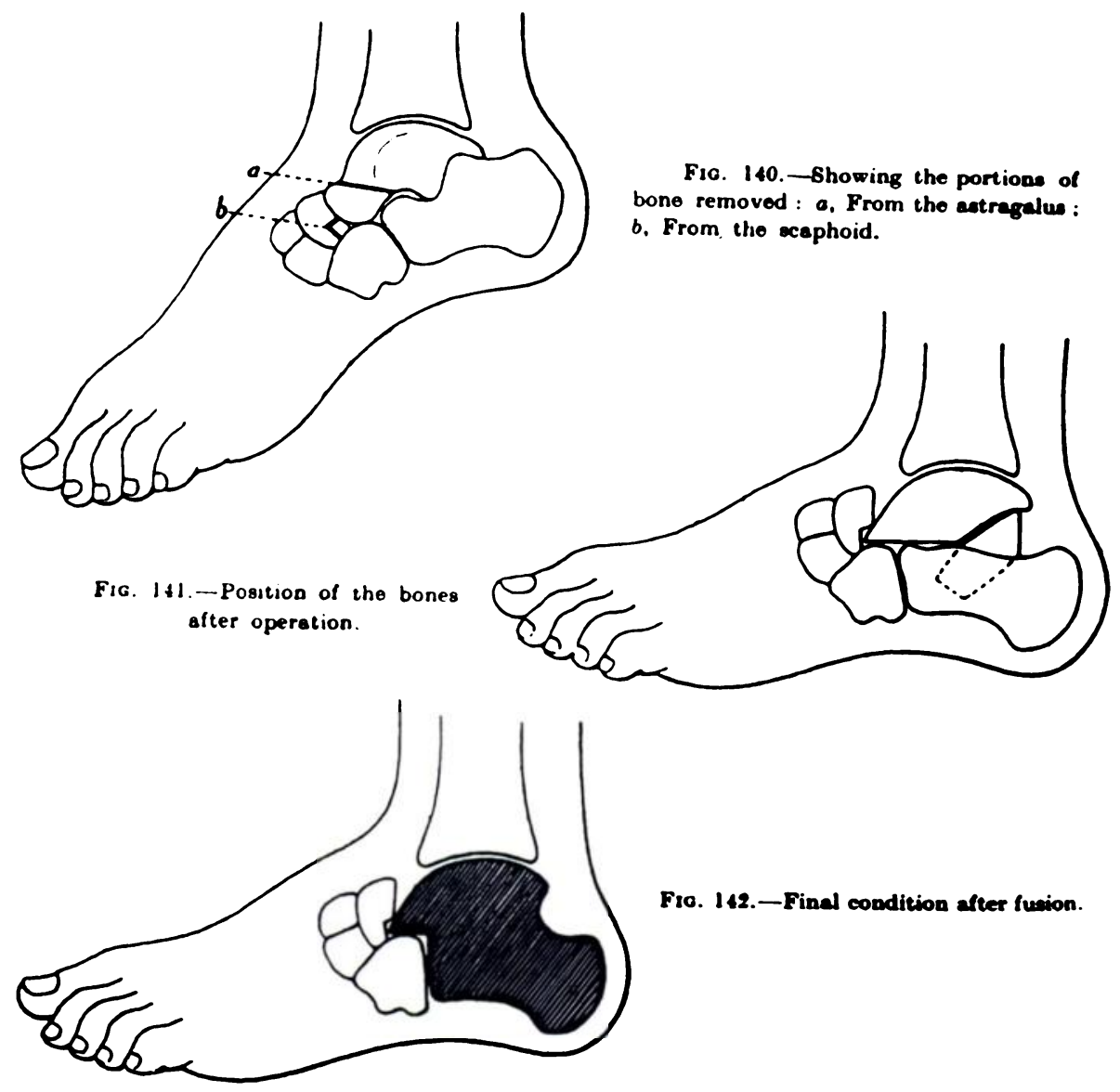

Lambrinudi's pictures from his article on the surgical treatment of drop-foot (British Journal of Surgery, 1927, volume 15, page 195). The lines of bone section were modified later.

Surgery began. In many ways, the inevitable loss to the British Journal of Surgery implicit in the creation of our own Journal has been a great pity, for orthopaedics had made its mark in the very beginnings of the older journal. Volume I, number 1, appeared in July 1913, with Sir Berkeley Moynihan as chairman of the editorial committee and Hey Groves as editorial secretary. Robert Jones was on the editorial committee. Rickman Godlee's introductory note apologised mildly for the appearance of yet another surgical journal. He should have boasted!

Robert Jones and Alwyn Smith were represented in the first number with their paper on rupture of the crucial ligaments; it includes the classic description of fractures of the tibial 


\section{FIBROCYSTIC DISEASE OF THE BONES. \\ BENIGN CYSTS, OSTEITIS FIBROSA, OSTEITIS FIBROSA WITH FORMATION OF TUMOURS AND GIANT-CELL SARCOMATA (VON RECKLINGHAUSEN), AND MOLLITIES OSSIUM WITH GIANT-CELL SARCOMATA.}

By R. C. ELMSLIE, London.

BLOodgood, writing upon this subject in 1910, opens his paper with the statement that in many surgical lesions technique is ahead of diagnosis. This statement undoubtedly contains a very important truth. The diagnosis of these obscure bone conditions is difficult, and at present uncertain; to many surgeons the very existence of bone cysts and the allied conditions is actually unknown; and this ignorance has led to the performance of operations of a magnitude which is not justified by the lesion present. In Germany, more particularly, another extreme has been reached. The number of cases placed upon record of bone cysts, osteitis fibrosa, etc., is very great. Each disscrtation upon the subject contains, as a rule, an elaborate pathological description of the specimens obtained, and a survey of the literature. But these investigations, valuable as they are, have been largely pathological, and have failed to classify the diseases upon any clinical system; and so they have not led to the record of a clear clinical picture which might assist subsequent observers in making a diagnosis. It is just this clinical picture

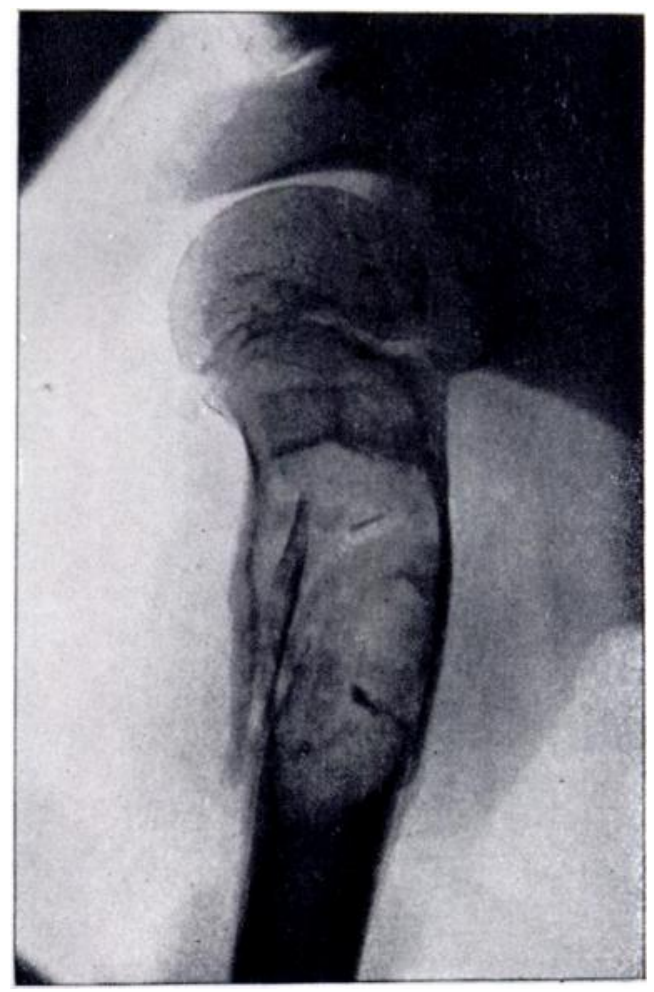

Fro. 12.-Radiograph of the hunnerus of E.O. at the time of the fracture. (Page 21.) which is wanting, and which the wealth of material at our disposal ought now to enable us to establish.

The history of solitary cysts of the long bones may be dated from the description in 1877 of a cyst in the upper end of the humerus found by Virchow 
in this connection the diagnostic line which, I have described upon several occasions will be found of great value. I append a short description. Any interference with the symmetry of this line should be regarded with apprehension.

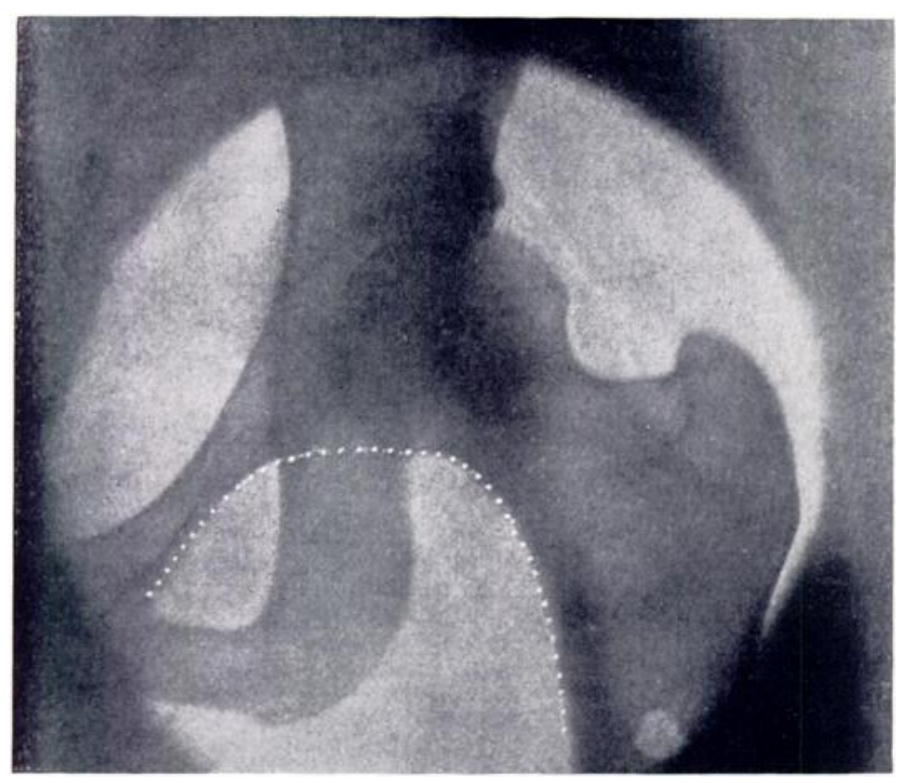

Fos: 28. - A nomal hip joint showing the ditgmontic line.

This line in all positions of the joint, i.c., abduction, adduction, etc., of the femur, is the same, an unbroken arch formed by the top of the obturattor foramen, and the inner side of the femoral neck. Imagination must connect these two lines before a perfect arch is formed, but a glance at Fig. 28 will 
spine. In the third number Hey Groves had a sixty-four page article on his experimental work on fractures which was later expanded into his book-there was no shortage of paper then! H. A. T. Fairbank wrote in the fourth number on congenital elevation of the scapula, describing eighteen cases with a beautifully illustrated dissection of a six-week-old patient who had Sprengel's shoulder and died of marasmus. In the second volume there was an important paper by R. C. Elmslie on fibrocystic disease. The unity of benign bone cysts and osteitis fibrosa was emphasized, and though the significance of Askanazy's association of osteitis fibrosa with the parathyroids (recorded in 1904) had been somewhat lost, Elmslie's paper is a classic. The author later had a share in one of the first cases of parathyroidectomy to be performed in this country and this also was reported in the British Journal of Surgery (Elmslie et al. 1933).

In the same journal appeared Fairbank on "Congenital Dislocation of the Hip " (1922), "Some General Diseases of the Skeleton" (1927), and "Fibrosis of Bone" (1939); Platt on "Pseudocoxalgia" (1922), which was the first British account of this disorder, with reports of thirty-five personal cases and a description of the evolution of the disease; Bankart on "Recurrent Dislocation of the Shoulder" (1938); Lambrinudi on "Drop-foot" (1927); and by R. W. Butler and H. J. Seddon on "Pott's Paraplegia" (1935).

The rest-The other outstanding communications which should be mentioned even in a brief review are largely those of the last ten or fifteen years and they are too recent for fair assessment. H. A. Brittain on ischio-femoral arthrodesis (1941), McMurray on intertrochanteric osteotomy (1936), many papers by Telford and others on cervical ribs and allied problems, Eden's expression of contrary views on the same subject (1939): these and many others must await the verdict of time. One recent book can surely face that judgment with confidenceWatson-Jones's Fractures and Joint Injuries, one of the few standard text-books of the English-speaking surgical world which-even in this Journal, which has its author as editor and shares its publisher-must be described as an outstanding credit to both.

Of the authors whose work has been borrowed to illustrate this paper, Sir Thomas Fairbank, Mr A. S. Blundell Bankart and Sir Arthur Keith are still alive and active in the pursuit of their scientific interests. Gratitude is particularly due to them for their kind permission to reproduce extracts from their work.

Most of the illustrations have been taken from published books and periodicals. All sources are mentioned in the captions but the author and the editor wish to record their thanks to publishers and editors who have given permission to reproduce illustrations and extracts. They are: The Editorial Secretary of the British Journal of Surgery; Messrs Butterworth \& Co.; the Editor of the Lancet; the Hon. Editor of the Liverpool Medico-Chirurgical Journal; Messrs James Maclehose \& Sons; Messrs Macmillan \& Co, Ltd.; the Medical Publishing Co. Ltd.; the Oxford University Press; and the Hon. Editor of the Proceedings of the Royal Society of Medicine.

\section{REFERENCES}

Bankart, A. S. B. (1938): The Pathology and Treatment of Recurrent Dislocation of the Shoulder Joint. British Journal of Surgery, 26, 23.

Bradford, E. H., and Lovetr, R. W. (1890): A Treatise on Orthopedic Surgery. New York: W. Wood \& Co. Brittain, H. A. (1941): Ischio-femoral Arthrodesis. British Journal of Surgery, 29, 93.

Butler, R. W. (1935): Paraplegia in Pott's Disease, with Special Reference to the Pathology and Etiology. British Journal of Surgery, 22, 738.

Eden, K. C. (1939): The Vascular Complications of Cervical Ribs. British Journal of Surgery, 27, 111.

ElmSLIE, R. C. (1914) : Fibrocystic Disease of the Bones. British Journal of Surgery, 2, 17.

Elmslie, R. C., Fraser, F. R., Dunhill, T. P., Vick, R. M., Harris, C. F., and Dauphinee, J. A. (1933): The Diagnosis and Treatment of Generalised Osteitis Fibrosa with Hyperparathyroidism. British Journal of Surgery, 20, 479.

Fairbank, H. A. T. (1914): Congenital Elevation of the Scapula. British Journal of Surgery, 1, 553.

Fairbank, H. A. T. (1922): Late Results of Treatment of Congenital Dislocations of the Hip. British Journal of Surgery, 10, 24.

Fairbank, H. A. T. (1927): Some General Diseases of the Skeleton. British Journal of Surgery, 15, 120. Fairbank, H. A. T. (1939): Increased and Decreased Density of Bone with Special Reference to Fibrosis of the Marrow. British Journal of Surgery, 27, 1. 
Groves, E. W. Hey (1914): An Experimental Study of the Operative Treatment of Fractures. British Journal of Surgery, 1, 438.

Groves, E. W. Hey (1916): On Modern Methods of Treating Fractures. Bristol: John Wright \& Sons Ltd. Jones, R. (1910): On Fractures in the Neighbourhood of Joints. Proceedings of the Royal Society of Medicine (Section of Surgery), 4, 1.

Jones, R. (1915): Injuries of Joints. London: Henry Frowde, Hodder and Stoughton.

Jones, R. (1917) : Notes on Military Orthopaedics. London: Cassell \& Co. Ltd.

Jones, R. (ed.) (1921): Orthopaedic Surgery of Injuries. By Various Authors. London: Henry Frowde, Hodder and Stoughton.

Jones, R., and Lovetr, R. W. (1923) : Orthopaedic Surgery. London: Henry Frowde, Hodder and Stoughton. Jones, R., and Sмiтh, S. A. (1913): On Rupture of the Crucial Ligaments of the Knee, and on Fractures of the Spine of the Tibia. British Journal of Surgery, 1, 70.

The Robert Jones Birthday Volume (1928): London: Humphrey Milford, Oxford University Press. Keith, A. (1919): Menders of the Maimed. London: Henry Frowde, Hodder and Stoughton.

Lambrinudi, C. (1927): New Operation on Drop-foot. British Journal of Surgery, 15, 193.

LANE, W. A. (1894): A method of treating Simple Oblique Fractures of the Tibia and Fibula more efficient than those in common use. Transactions of the Clinical Society of London, 27, 167.

Macewen, W. (1912): The Growth of Bone. Glasgow: James Maclehose \& Sons.

MACEWEN, W. (1923): On the study of nature as shedding light on the structure and functioning of man: the antler of the deer in its relation to the growth of bone.

McMurray, T. P. (1936) : Ununited Fractures of the Neck of the Femur. Journal of Bone and Joint Surgery, 18, 319.

Platt, H. (1922): Pseudo-coxalgia. British Journal of Surgery, 9, 366

Seddon, H. J. (1935): Pott's Paraplegia: Prognosis and Treatment. British Journal of Surgery, 22, 769.

Telford, E. D., and Stopford, J. S. B. (1931): The Vascular Complications of Cervical Rib. British Journal of Surgery, 18, 557.

TubBy, A. H. (1896): Deformities. London: Macmillan \& Co.

TubBy, A. H., and Jones, R. (1903): Modern Methods in the Surgery of Paralysis. London: Macmillan \& Co. Watson, F. (1934): The Life of Sir Robert Jones. London: Hodder and Stoughton Ltd.

Watson-Jones, R. (1943) : Fractures and Joint Injuries. Third edition. Edinburgh : E. \& S. Livingstone Ltd. 